\title{
SKIRTINGŲ KINEZITERAPIJOS PROGRAMU巳 POVEIKIS KAKLINĖS STUBURO DALIES SKAUSMUI IR SUTRIKUSIAI FUNKCINEI BŪKLEI
}

\author{
Akvilè Jankauskaitė, Saulė Sipavičienė \\ Lietuvos sporto universitetas
}

\section{SANTRAUKA}

Tyrimo pagrindimas. Mokslininkų teigimu, kaklo skausmas yra globalus sveikatos sutrikimas, kuris paveikia žmogaus gyvenimo kokybę. Dẻl skirtingai vertinamų metodikų stinga tyrejjų nuomonès, kokia kineziterapijos intervencija yra veiksmingiausia mažinant kaklinės stuburo dalies skausmą, todèl pasirinkome palyginti tris skirtingas intervencijas.

Tikslas. Nustatyti skirtingų kineziterapijos metodų poveikị stuburo kaklinès dalies skausmui ir sutrikusiai funkcinei būklei.

Metodai. Buvo tiriami 89 asmenys, kurie skundèsi nespecifinio pobūdžio lètiniu kaklo skausmu. Tiriamieji buvo suskirstyti ị tris grupes. Pirmai grupei buvo taikomi gydomieji pratimai, antrai grupei - gydomieji pratimai ir vakuuminès taurès, trečiai grupei - gydomieji pratimai ir kinezioteipavimas. Prieš intervencijas ir po jų buvo ịvertinta tiriamųju gyvenimo kokybė, funkciné negalia, skausmas bei kaklo judesių amplitudès.

Rezultatai. Po reabilitacijos pastebėti visų grupių tiriamujjų statistiškai reikšmingai pagerèję rodikliai. Po tyrimo skausmas sumažèjo visose grupèse. Palyginus rodiklius tarp grupių, pastebèti geresni gydomujų pratimų ir vakuuminių taurių grupès rodikliai, šios grupès tiriamiesiems reikšmingai sumažèjo skausmo intensyvumas, padidejo kaklo judesių amplitudès ir pagerèjo gyvenimo kokybė $(\mathrm{p}<0,05)$.

Išvada. Gydomieji pratimai su vakuuminemis taurèmis labiau sumažino skausmo intensyvumą ir funkcinę negalią, aktyvių galvos judesių amplitudė padidèjo labiau nei taikant kitas kineziterapines programas.

Raktažodžiai: kaklo skausmas, kinezioteipavimas, vakuuminès taurès, gydomieji pratimai.

\section{IVADAS}

Šiuolaikiniame pasaulyje apie 80 proc. žmonių patiria kaklo skausmą (Cohen et al., 2015). Mokslininkai daug dėmesio skiria kaklinès stuburo dalies skausmui gydyti (Langevin et al., 2015). Viena dažniausių griaučių ir raumenų sistemos problemų, ypač žmonių, dirbančių sẻdimą darbą, kaklo skausmas. Ilgą laiką raumenims būnant susitraukimo būsenoje sutrinka kraujotaka, vystosi išemija, užspaudžiami kapiliarai, ị raumenis nepriteka pakankamai kraujo, nepatenka deguonis bei energinès medžiagos. Visa tai sąlygoja uždegimo, skausmo, raumenų įtampos

Copyright (C) 2021 Akvilè Jankauskaitė, Saule Sipavičienė. Published by Lithuanian Sports University. This is an Open Access article distributed under the terms of the Creative Commons Attribution 4.0 International License, which permits unrestricted use, distribution, and reproduction in any medium, provided the original author and source are credited. 
atsiradimą, sukelia griaučiu ir raumenų sistemos pažeidimą, pokyčiai yra ilgalaikiai (Langevin et al., 2015).

F. Saha, R. Lauche, H. Cramer et al. (2012) tyrimo duomenimis, vakuuminės taurès veiksmingai padeda ir gydant kaklinès stuburo dalies skausmus. Tyrẻjai nustatè, kad jau po vienos procedūros reikšmingai sumažèja skausmas, pagerēja gyvenimo kokybė bei fizinès funkcijos (Saha, Schumann, Cramer et al., 2012). R. Cramer (2020), atlikęs tyrimų apie vakuuminių taurių naudą kaklinės stuburo dalies skausmams gydyti metaanalizę, nustatè, kad visuose tyrimuose vakuuminès taurès veiksmingai mažino skausmą. Gydant kaklinès stuburo dalies skausmą, dažnai taikomas kineziterapijos metodas - kinezioteipavimas. F. Reynard (2018) teigimu, kinezioteipavimas - tai gydymo metodas, kai klijuojamas lipnusis elastinis pleistras, kuris naudoja raumens homeostazines savybes simptomams bei skausmui malšinti. Naudojant kinezioteipą, normalizuojama raumenų jèga, įtampa ir spazmai, palengvinama kraujo, limfos, audinių ir skysčių apykaita. Kinezioteipavimas gana lengvai taikomas metodas, skatinantis raumenų aktyvinimą (Ganesh et al., 2016). Šio metodo veikimo principas - padèti susitraukti silpnam raumeniui (Dilek et al., 2016). Kinezioteipavimo poveikio veiksmingumui įtakos turi du veiksniai: tinkamas asmens būklès ịvertinimas bei tinkamos kinezioteipavimo technikos parinkimas.

Tyrimo tikslas - nustatyti skirtingų kineziterapijos metodų poveikị stuburo kaklinès dalies skausmui ir sutrikusiai funkcinei būklei.

\section{METODAI}

Tiriamieji. Tyrime dalyvavo 89 tiriamieji. Tiriamujų amžius buvo 40,6 $\pm 9,7$ metai; ūgis - 171,15 $\pm 6,45 \mathrm{~cm}$; svoris $-61,59 \pm 11,40 \mathrm{~kg}$; KMI $-20 \pm 2,9 \mathrm{~kg} / \mathrm{m}^{2}$. Jie buvo suskirstyti atsitiktine tvarka ị tris grupes. Pirmai tiriamujų grupei taikyti gydomieji pratimai; antrai - gydomieji pratimai ir vakuuminès taurès; trečiai grupei - gydomieji pratimai ir kinezioteipavimas. Tiriamujų įtraukimo ị tyrimą kriterijai: jaučiantys kaklo skausmą ne mažiau nei du mėnesius, darbingas amžius (30$65 \mathrm{~m}$.). Atmetimo kriterijai: aukštas arterinis kraujo spaudimas (sistolinis didesnis nei $120 \mathrm{~mm} \mathrm{Hg}$ ir (arba) diastolinis didesnis nei $80 \mathrm{~mm} \mathrm{Hg}$ ), širdies ir kraujagyslių sistemos ligos, buvusios traumos, nëštumas, nesutikimas dalyvauti tyrime.

Tyrimo metodai

Skausmo vertinimas. Kaklinès stuburo dalies skausmas vertintas Analogine skausmo skale (SAS). Tyrimo pradžioje ir pabaigoje tiriamųų buvo prašoma ịvertinti jaučiamo skausmo intensyvumą. Vertinamas didžiausias skausmas nuo 0 iki 10, jaučiamas kaklo ir pečiu lanko srityje. Skausmo vertinimo skalè: 0 balų skausmo nèra; 1-3 balai - jaučiamas silpnas skausmas, kuris sumažèja pakeitus 
padètį; 4-5 balai - jaučiamas nestiprus skausmas; $6-7$ balai - jaučiamas pakenčiamas nuolatinis skausmas, kuris stipreja judant, tačiau pacientas gali atlikti daugeli judesių; 8 balai - jaučiamas stiprus skausmas, dèl kurio pacientas negali susikoncentruoti ir atlikti paprastų judesių; 9-10 balų - jaučiamas labai stiprus skausmas, kuris neleidžia atlikti jokio judesio.

Kaklo judesių amplitudžių vertinimas goniometru. Tyrimo pradžioje ir pabaigoje buvo atliekamas galvos judesių amplitudžių matavimas. Buvo vertinami šie galvos judesiai: lenkimas, tiesimas.

Kaklo funkcinès negalios vertinimas. Tyrimo pradžioje Kaklo negalios indekso (KNI) klausimynu buvo ịvertinta kaklo skausmų ịtaka tiriamujų kasdieniams darbams, apsitarnavimui, daiktų kèlimui, judejjimui, miegui, laisvalaikiui, susikoncentravimui ir vairavimui. Didžiausias galimas KNI surinktų balų skaičius buvo 50. Kuo aukštesnis rezultatas, tuo didesnę negalią jis rodo.

Funkcinès negalios vertinimas. Buvo ịvertinama funkcinè negalia (Gatchel et al., 2006) Oswestry klausimynu (angl. Oswestry Disability Index). Klausimyną sudaro 10 klausimų, kiekvienas iš jų turi po šešis atsakymo variantus (A-F). Tiriamasis pasirenka vieną, labiausiai jo būklę atspindintị atsakymo variantą. Kiekviena Owestry klausimyno raide atitinka tam tikrą balą nuo 0 iki 5: A - $0, \mathrm{~B}-1$, $\mathrm{C}-2, \mathrm{D}-3, \mathrm{E}-4, \mathrm{~F}-5$. Didžiausia galima balų suma -50 balų, mažiausia -0 balų. Kuo didesnis surinktas balų skaičius, tuo skausmo ịtaka paciento funkcinei būklei stipresnè, surinktas mažesnis balų skaičius - atvirkščiai. Gauta balų suma verčiama ị procentus pagal formulę: balų suma: 50 x $100=$ procentinè išraiška (proc.). Išvada daroma atsižvelgiant ị procentinę išraišką: 0-20 proc. - minimalus funkcijos pažeidimas, 21-40 proc. - vidutinis funkcijos pažeidimas, 41-60 proc. sunkus funkcijos pažeidimas, $61-80$ proc. - negalia, $81-100$ proc. - lovos režimas, simuliuojami simptomai.

Tyrimo organizavimas ir eiga. Tyrimas truko 12 sav., penkios procedūros per savaitę, procedūros trukmè po 20-30 min. Tyrimui atlikti buvo gautas LSU Bioetikos komiteto leidimas Nr. NR. MNL-KIN(M)-2020-245 bei visų tyrimo dalyvių sutikimas. Prieš ir po tyrimo pacientams ịvertinta kaklo judesių amplitudè, skausmas - Analogine skausmo skale, gyvenimo kokybe - Oswestry klausimynu ir Kaklo negalios indeksu. Kaip buvo atliekamas tyrimas, pateikiama 1 pav.

Matematinè statistika. Tyrimo duomenų statistinès analizès metu buvo naudojama „SPSS 17.0“ versija. Diagramoms pavaizduoti buvo naudojama „MS Excel 2010“ programa. Buvo apskaičiuojamas kiekybinių rodikliu aritmetinis vidurkis, standartinis nuokrypis (SN). Kineziterapijos poveikiui vertinti buvo naudojami neparametriniai Mann'o-Whithey'aus kriterijai nepriklausomoms imtims ir Wilcoxon priklausomoms imtims lyginti. Nepriklausomų imčių Mann'o-Whithey'aus testas buvo taikomas palyginus nepriklausomas tiriamujų grupes (turinčius ir neturinčius nagrinëjamo požymio). Duomenų skirtumas statistiškai reikšmingas ir patikimas, kai $\mathrm{p}<0,05$. 


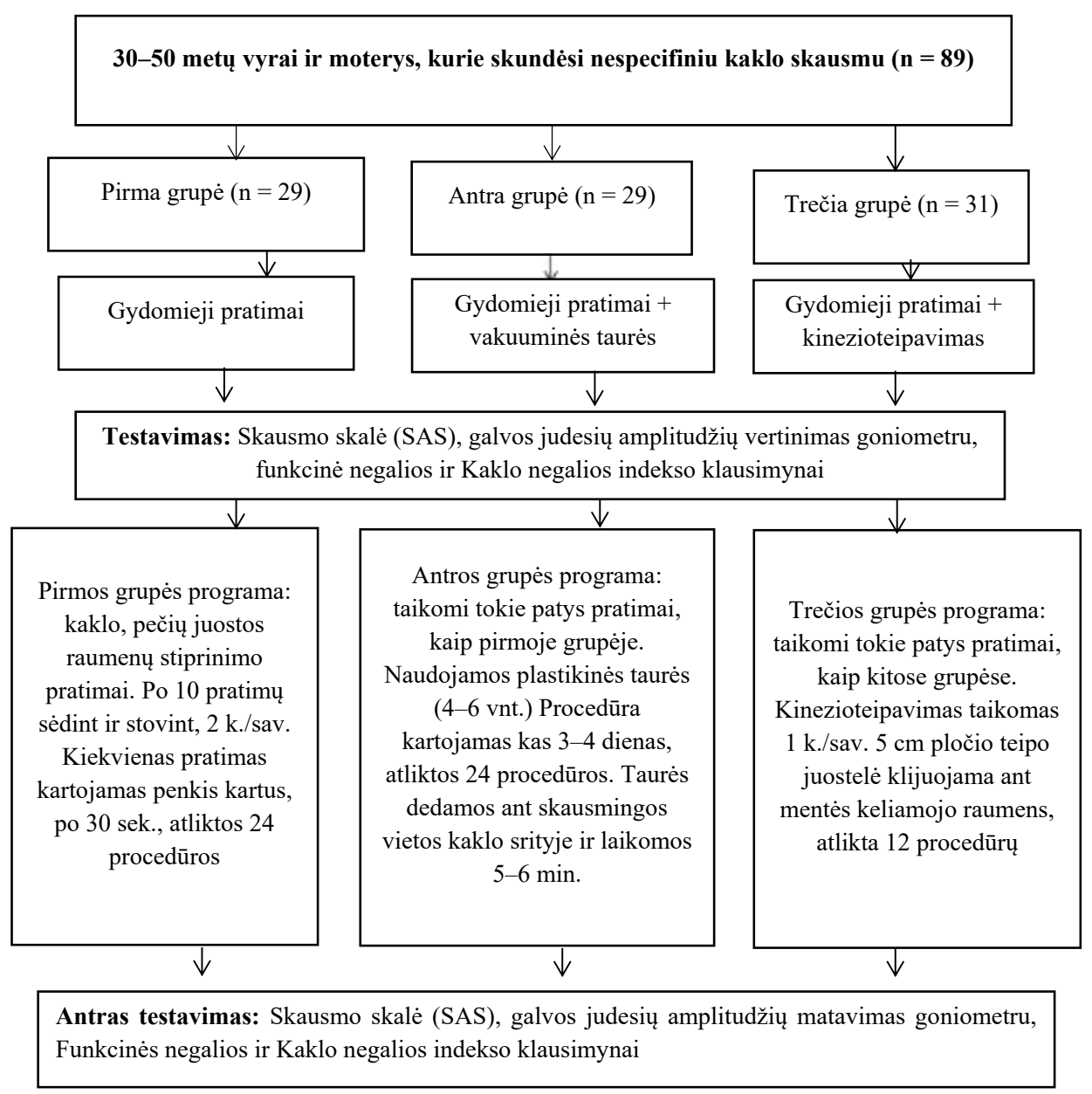

\section{1 pav. Tyrimo organizavimo schema}

\section{TYRIMO REZULTATAI}

2 pav. pateikiami gydomųjų pratimų grupės, gydomųų pratimų ir vakuuminių taurių grupès bei gydomụjų pratimų ir kinezioteipavimo grupès skausmo rodikliai. Po 12 savaičių intervencijos, taikant skirtingas kineziterapijos priemones, skausmo intensyvumo rodikliai statistiškai reikšmingai pagerèjo $(\mathrm{p}<0,05)$ visose tiriamujjų grupèse. Po procedūrų labiausiai skausmas sumažèjo tiems tiriamiesiems, kuriems taikyti gydomieji pratimai ir vakuuminès taurès, o mažiausiai - tiems, kuriems taikyti tik gydomieji pratimai. Gydomujų pratimų ir vakuuminių taurių 


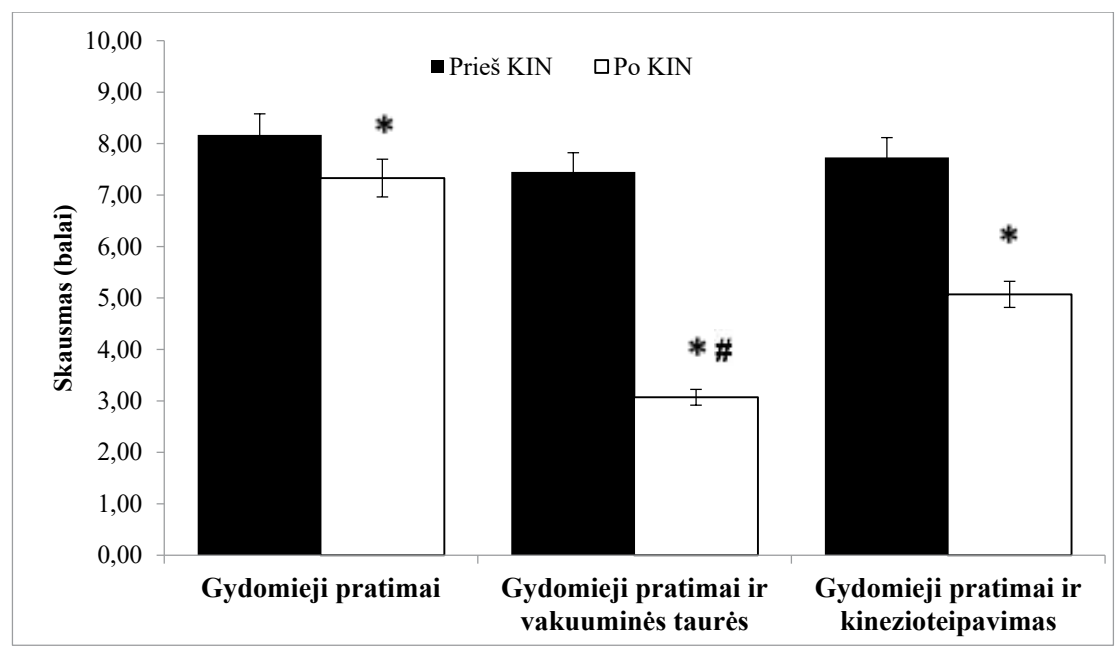

\section{2 pav. Skausmo balų rodikliai prieš kineziterapiją ir po jos}

Pastaba. ${ }^{*} \mathrm{p}<0,05$ palyginus rodiklius prieš kineziterapiją ir po jos, \#p $<0,05$ palyginus gydomujų pratimų ir gydomųjų pratimų + vakuuminių taurių grupès po kineziterapijos metodų taikymo.

grupès tiriamiesiems skausmas reikšmingai sumažèjo daugiau nei gydomujų pratimų grupès tiriamiesiems $(\mathrm{p}<0,05)(2$ pav. $)$.

3 pav. pateikiami gydomuju pratimu grupès, gydomuju pratimų ir vakuuminių taurių grupès bei gydomujų pratimų ir kinezioteipavimo grupės kaklo negalios indekso rodikliai. Po 12 sav. intervencijos, taikant skirtingas kineziterapijos priemones, kaklo negalios indekso rodikliai statistiškai reikšmingai pagerejjo (p < $0,05)$ visose tiriamujjų grupese ( 3 pav.). KNI balas sumažejo taikant gydomuosius pratimus su vakuuminèmis taurèmis nuo 37,59 iki 20,14 balo, o gydomujų pratimų vienų ir kinezioteipavimo rezultatai buvo statistiškai reikšmingesni palyginus su gydomujų pratimų grupe $(\mathrm{p}<0,05)$. Tyrimo pabaigoje vertinant KNI pokytị, 36,72 balo tyrimo pradžioje ir 24,62 balo tyrimo pabaigoje, o gydomieji pratimai atskirai - nuo 36,97 iki 27,31 balo (p < 0,05) (3 pav.).

4 pav. pateikiami gydomujų pratimų grupès, gydomujų pratimų ir vakuuminių taurių grupès bei gydomujų pratimų ir kinezioteipavimo grupès funkcinès negalios rodikliai. Funkcinė negalia labiausiai sumažejjo taikant gydomuosius pratimus ir vakuumines taures nuo 35,24 iki 20 balų. Mažiau efektyvus buvo kinezioteipavimas taikytas kartu su gydomaisiais pratimais: pokytis nuo 35,90 iki 23,86 balo. Vien gydomieji pratimai palyginus su papildomai naudojamu kinezioteipavimu arba vakuuminèmis taurèmis pasirodè mažiausiai veiksmingi, pokytis siekè nuo 34,31 balo procedūrų pradžioje iki 26,93 balo po kineziterapijos. Gydomuju pratimų ir 
- Prieš KIN $\square$ Po KIN

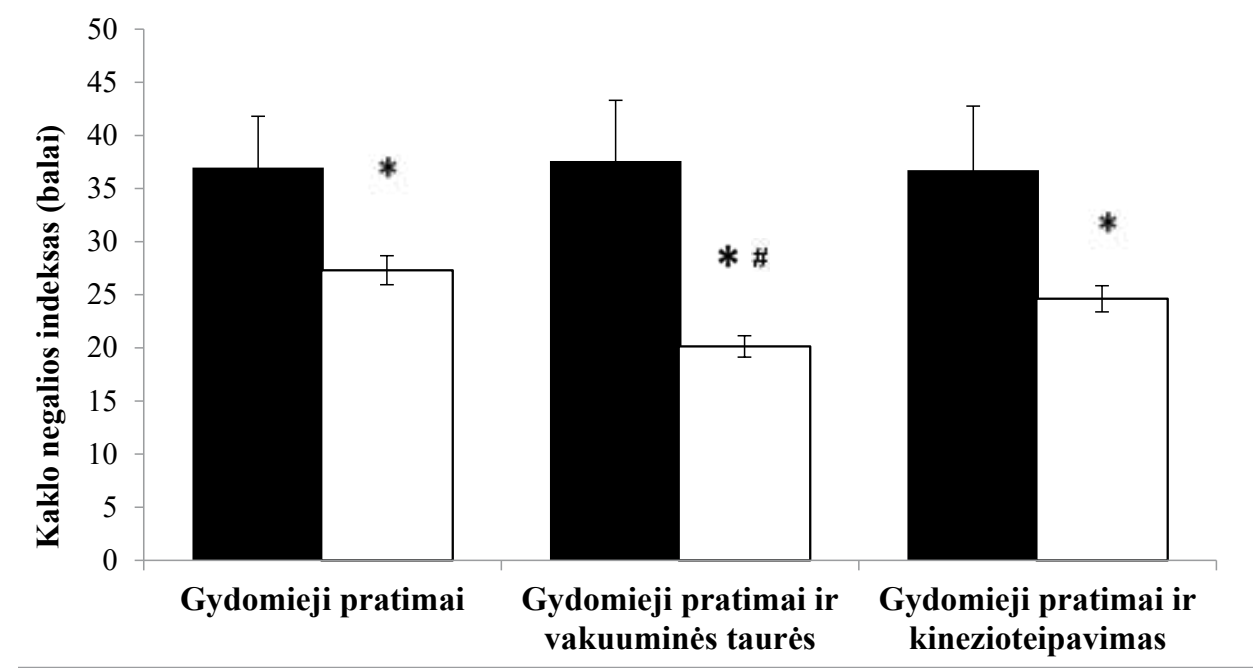

3 pav. Kaklo negalios indekso rodikliai

Pastaba. ${ }^{*} \mathrm{p}<0,05$ palyginus rodiklius prieš kineziterapiją ir po jos, $\# \mathrm{p}<0,05$ palyginus gydomujų pratimų ir gydomujų pratimų + vakuuminių taurių grupès.

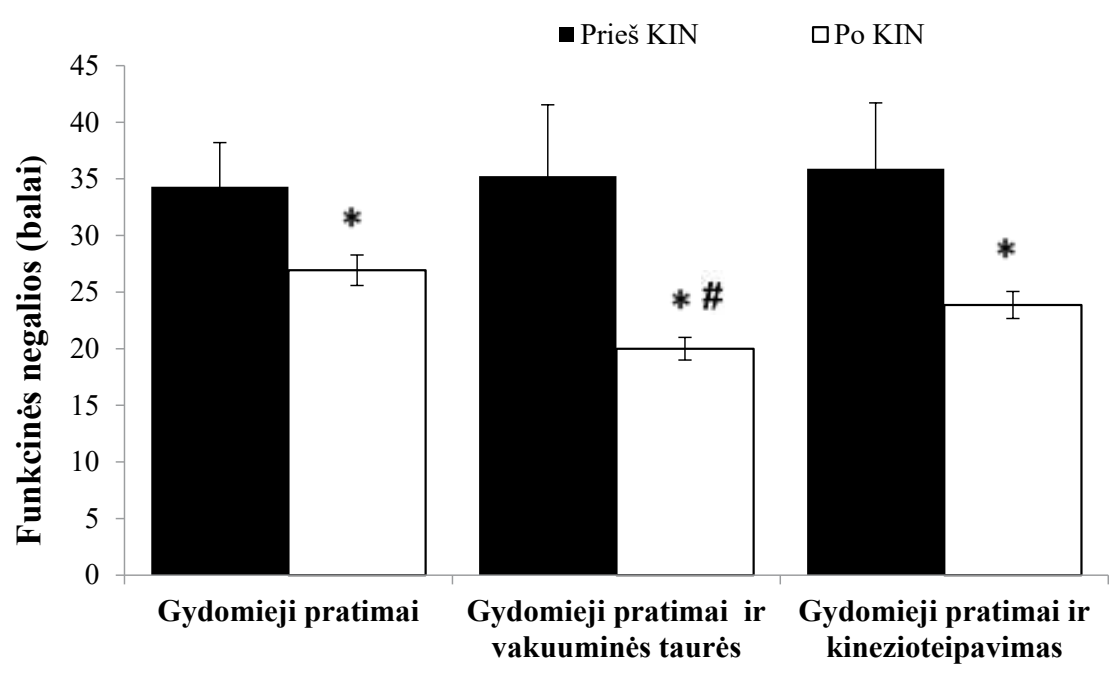

\section{4 pav. Funkcinès negalios rodikliai}

Pastaba. ${ }^{*} \mathrm{p}<0,05$ palyginus rodiklius prieš kineziterapiją ir po jos, $\# \mathrm{p}<0,05$ palyginus gydomujų pratimų ir gydomujų pratimų + vakuuminių taurių grupès. 
vakuuminiu tauriu poveikis buvo geresnis, palyginus su gydomaisiais pratimais $\mathrm{p}<0,05$ (2 pav.).

5 pav. pateikiami gydomujų pratimų grupès, gydomujjų pratimų ir vakuuminių taurių grupès bei gydomujju pratimų ir kinezioteipavimo grupės galvos lenkimo amplitudè. Po 12 sav. intervencijos, pritaikius skirtingas kineziterapijos priemones, gydomujų pratimų grupeje buvo nustatytas $0,53 \pm 1,0$ pokytis, tai statistiškai nereikšmingas pokytis $(\mathrm{p}<0,001)$; gydomujų pratimų ir vakuuminių taurių grupèje nustatytas $5,21 \pm 1,3$ statistiškai reikšmingas $(\mathrm{p}<0,05)$ pokytis; gydomujų pratimų ir kinezioteipavimo grupeje nustatytas $2,31 \pm 1,0$ statistiškai reikšmingas $(\mathrm{p}<0,05)$ pokytis $(5$ pav. $)$.

6 pav. pateikiami gydomuju pratimų grupès, gydomujų pratimų ir vakuuminių taurių grupès bei gydomųjų pratimų ir kinezioteipavimo grupès tiriamuju galvos tiesimo amplitudès pokyčiai. Galvos tiesimo amplitudè po gydomųų pratimų buvo 0,96 laipsniai grupeje, kurioje taikytas kinezioteipavimas - pokytis po procedūru 3,49 laipsniai. Tačiau veiksmingiausia priemone, norint pagerinti galvos tiesimo amplitudę, yra gydomieji pratimai ir vakuuminių taurių naudojimas, palyginus su tik gydomaisiais pratimais $(\mathrm{p}<0,05)(6$ pav. $)$.

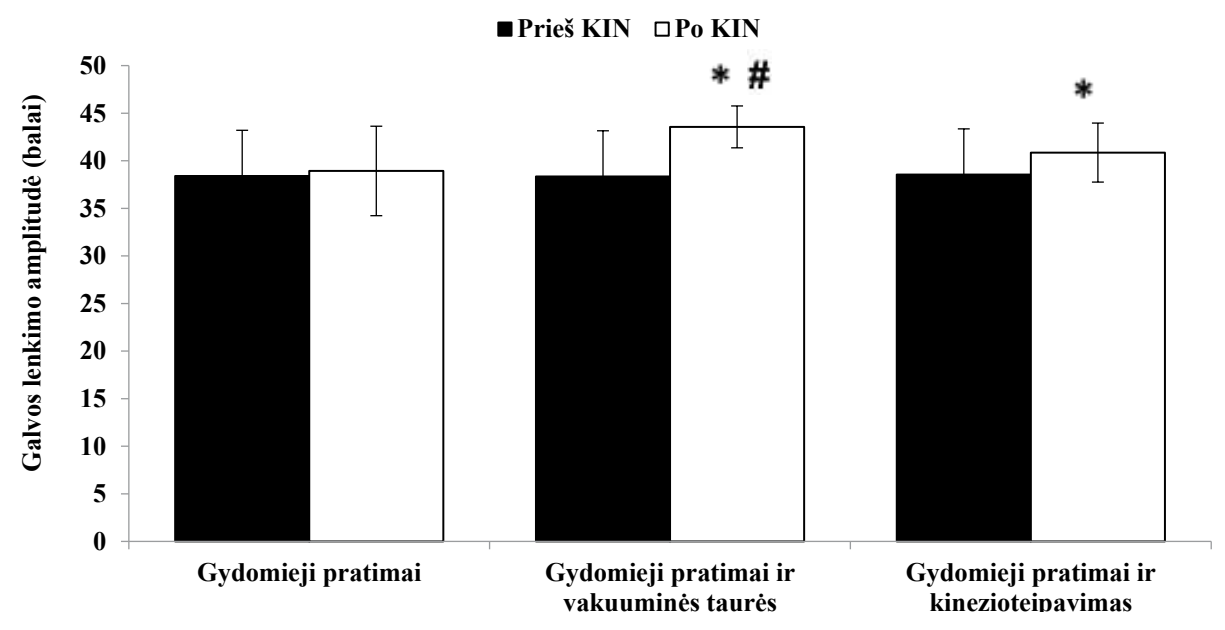

\section{5 pav. Galvos lenkimo amplitudė}

Pastaba. * $\mathrm{p}<0,05$ palyginus rodiklius prieš kineziterapiją ir po jos, \#p $<0,05$ palyginus gydomujų pratimų ir gydomujų pratimų + vakuuminių taurių grupès. 
๑ Prieš KIN $\square$ Po KIN
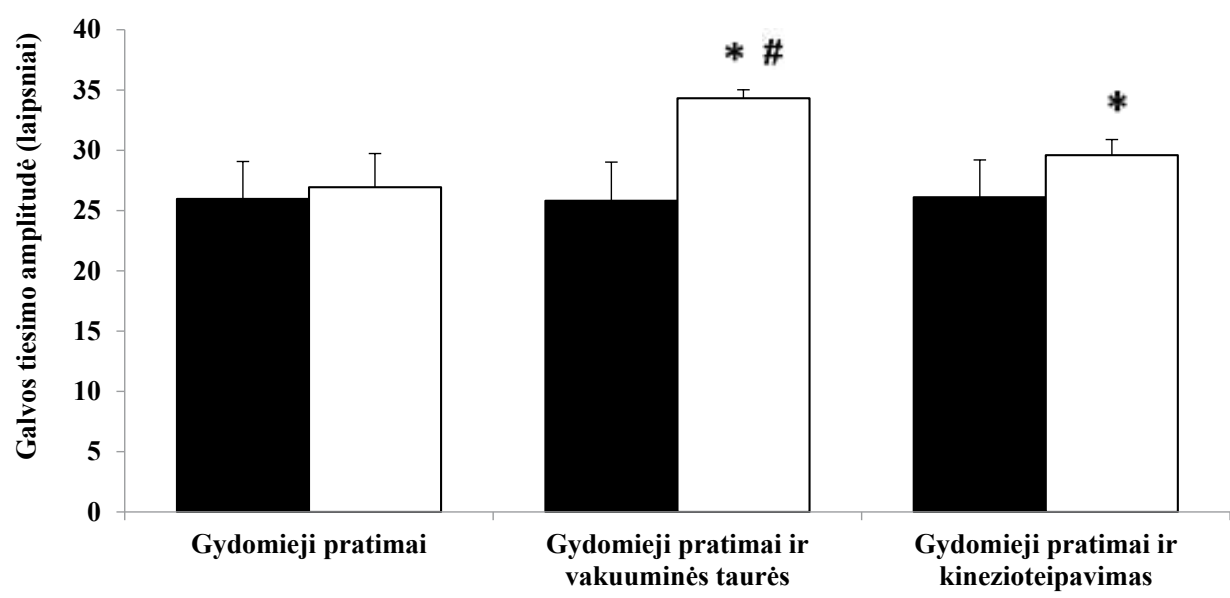

5 pav. Galvos tiesimo amplitudès rodikliai

Pastaba. ${ }^{*} \mathrm{p}<0,05$ palyginus rodiklius prieš kineziterapiją ir po jos, $\# \mathrm{p}<0,05$ palyginus gydomujų pratimų ir gydomųjų pratimų + vakuuminių taurių grupés.

\section{REZULTATŲ APTARIMAS}

Tyrimo tikslas buvo nustatyti skirtingų kineziterapijos metodų poveikị stuburo kaklinès dalies skausmui. Mūsų tyrimo duomenimis po 12 sav. kineziterapijos procedūrų sumažèjo skausmo intensyvumas, funkcinè negalia, Kaklo negalios indeksas ir padidejo galvos judesių amplitudès.

M. K. Zebis et al. autorių (2014) tyrime taip pat pastebètas reikšmingas kaklo skausmo pokytis po 10 sav. treniruočių - skausmo intensyvumas sumažejo 36 proc. Palyginome mūsų duomenis su K. De Meulemeester (2017) duomenimis: šiame tyrime po 10 gydymo sav. taikant gydomuosius pratimus kartu su vakuuminėmis taurėmis padidèjo galvos kaklo judesių amplitudès, tačiau, taikant tik pratimus su pasipriešinimo gumomis, kaklo judesių amplitudè žymiai nepakito, tai pastebèta ir mūsų tyrime.

L. Costa (2008) tyrimo rezultatai sutampa su mūsų. Jie parodè, kad, derinant kineziterapiją su vakuuminèmis taurèmis, labiausiai sumažeja kaklo skausmo intensyvumas ir funkcinè negalia. R. Lauche, H. Cramer, C. Hohmann et al. (2012) atliktas tyrimas parodé, kad vakuuminès taurès veiksmingai gydo kaklinès stuburo dalies skausmus. Tyrejai nustate, kad jau po vienos procedūros reikšmingai sumažèja skausmas, pagerẻja gyvenimo kokybė bei fizinės funkcijos. J. Kim (2018) atliko tyrimą apie vakuuminių taurių naudą gydant kaklinės stuburo dalies skausmus 
ir nustatè, kad vakuuminès taurès sumažino kaklo skausmą. Tiriamieji teigè, jog nejaute įtampos kaklo srityje, kurią jautè prieš tyrimą (Kim, 2018).

Mūsų tyrimas parodè, kad gydomieji pratimai ir kinezioteipavimo priemonès mažina kaklinès stuburo dalies skausmą, didina judesių atlikimo amplitudę. Rezultatas būtų ypač geras, jeigu kineziterapiniai užsièmimai tęstųsi ilgai, t. y. metus ir ilgiau (Sahin et al., 2018).

K.P. Sanjay et al. (2013) įrodè kinezioteipavimo metodikos veiksmingumą kaklo griaučių ir raumenų sistemos sutrikimams gydyti. Keturias savaites taikant gydomuosius pratimus kartu su kinezioteipavimu būna reikšmingas trumpalaikis ir nereikšmingas ilgalaikis poveikis lètiniam kaklo skausmui, negalios mažejjimui ir aktyvių judesių amplitudès didejimui palyginus vien tik su gydomujjų pratimų poveikiu (Sanjay, 2013). Panašius rezultatus gavo G. Iglesias et al. (2009), jie nustatè, kad kaklo srities skausmai reikšmingai mažèja ir kaklo judesių amplitudès reikšmingai didejja, kai gydomieji pratimai taikomi kartu su kinezioteipavimu arba vakuuminèmis taurèmis.

Tyrimo pradžioje buvo iškelta hipotezè, kad gydomujų pratimų derinimo su vakuuminėmis taurėmis rezultatai gydant kaklo stuburinės dalies skausmą geresni nei vien gydomųų pratimų. Mūsų tyrimo rezultatai, kaip ir kitų autorių, iš dalies patvirtino prielaidą, kad vakuuminès taurès veiksmingai malšina kaklo skausmą, tačiau reikalingi tolesni tyrimai.

\section{IŠVADA}

Gydomųų pratimų ir vakuuminių taurių derinimas labiau sumažino skausmo intensyvumą ir funkcinę negalią, aktyvių galvos judesių amplitudè padidèjo labiau nei taikant kitas kineziterapines programas.

Finansavimas: nèra.

Interesų atskleidimas: nėra.

\section{LITERAT ŪRA}

Andersen, L. L., Kjaer, M., Sögaard, K. et al. (2008). Effect of two contrasting types of physical exercise on chronic neck muscle pain. Arthritis Care \& Research: Official Journal of the American College of Rheumatology, 59 (1), 84-91.

Campa-Moran, I., Rey-Gudin, E., Fernández-Carnero, J. et al. (2015). Comparison of dry needling versus orthopedic manual therapy in patients with myofascial chronic neck pain: a single-blind, randomized pilot study. Pain research and treatment, 2015.

Cheung, J., Kajaks, T., MacDermid, J. C. (2013). Suppl 4: The Relationship Between Neck Pain and Physical Activity. The Open Orthopaedics Journal, 7, 521.

Cohen, S. P. (2015). Epidemiology, Diagnosis, And Treatment Of Neck Pain. In Mayo Clinic Proceedings, 90 (2), 284-299. 
Costa, M. (2008). Treatment of a patient with cervical radiculopathy using thoracic spine thrust manipulation, soft tissue mobilization, and exercise. Journal of Manual \& Manipulative Therapy 129-135.

De Meulemeester, K. E., Castelein, B., Coppieters, I. et al. (2017). Comparing Trigger Point Dry Needling And Manual Pressure Technique For The Management Of Myofascial Neck/Shoulder Pain: A Randomized Clinical Trial. Journal Of Manipulative And Physiological Therapeutics, 40 (1), 11-20.

Dilek, B., Batmaz, I., Sarıyıldız, M. A. et al. (2018). Kinesio taping in patients with lateral epicondylitis. Journal of back and musculoskeletal rehabilitation, 29 (4), 853-858.

Farooq, M. N., Mohseni-Bandpei, M. A., Gilani, S. A. et al. (2018). The effects of neck mobilization in patients with chronic neck pain: A randomized controlled trial. Journal of Bodywork and Movement Therapies, Vol. 22.

Ganesh, G. S., Mohanty, P., Pattnaik, M., \& Mishra, C. (2015). Effectiveness of mobilization therapy and exercises in mechanical neck pain. Physiotherapy theory and practice, 31 (2), 99-106.

GonzáLez-Iglesias, J., Fernández-de-Las-Peñas, C., Cleland, J. et al. (2009). Short-term effects of cervical kinesio taping on pain and cervical range of motion in patients with acute whiplash injury: a randomized clinical trial. Journal of orthopaedic \& sports physical therapy, 39 (7), 515-521.

Kim, J., Kim, S., Shim, J. et al. (2018). Effects Of Mckenzie Exercise, Kinesio Taping, And Myofascial Release On The Forward Head Posture. Journal Of Physical Therapy Science, 30 (8), 1103-1107.

Langevin, P., Desmeules, F., Lamothe, M. et al. (2015). Comparison Of 2 Manual Therapy And Exercise Protocols For Cervical Radiculopathy. Journal Of Orthopaedic \& Sports Physical Therapy, 45 (1), 4-17.

Lauche, R., Cramer, H., Hohmann, C. et al. (2012). The effect of traditional cupping on pain and mechanical thresholds in patients with chronic nonspecific neck pain: a randomised controlled pilot study. EvidenceBased Complementary and Alternative Medicine, 45 (1), 16-20.

Lee, N., Kim, S., Shim, J. et al. (2013). Effects Of Mckenzie Exercise, Kinesio Taping, And Myofascial Release On The Forward Head Posture. Journal Of Physical Therapy Science, 30 (8), 1103-1107.

Sanjay, K. P, Babu, V. K, Kumar, N. (2013). Short term efficacy of kinesioteping of chronic mechanical neck pain. Int J Physiother Res. 1 (5), 283-392.

Sowmya, M. V. (2014). Isometric Neck Exercises versus Dynamic Neck Exercises in Chronic Neck Pain. Journal of Nursing and Health Science, 3 (2), 32-43.

Zebis, M. K., Andersen, C. H., Sundstrup, E. et al. (2014). Time-wise change in neck pain in response to rehabilitation with specific resistance training: implications for exercise prescription. PloS one, 9 (4).

Juocevičius, A., Varnienė, L., Matulevič, R. et al. (2014). Skirtingų Kineziterapijos Metodų Veiksmingumas Kaklinès Dalies Skausmą Patiriantiems Biuro Darbuotojams. Gerontologija, 15 (3), 177-183.

\title{
EFFECT OF DIFFERENT PHYSIOTHERAPY PROGRAMS ON CERVICAL SPINE PAIN AND FUNCTIONAL CONDITION
}

\author{
Akvilè Jankauskatė, Saulė Sipavičienė \\ Lithuanian Sports University
}

ABSTRACT

Background. Scientists say neck pain is a global health disorder that changes a person's quality of life. Due to the differently evaluated methodologies, researchers lack an opinion on which physiotherapy intervention is most effective in reducing cervical spine pain, thus the comparison of three different interventions is presented in this study. 
Aim. To determine the effect of different physiotherapy methods on neck pain and function.

Methods. 89 individuals with non-specific chronic neck pain were studied. Subjects were divided into three groups. Therapeutic exercises were applied in group one, therapeutic exercises and vacuum cups in group two, and therapeutic exercises and kinesio taping were applied in group three. Before and after the interventions, patients' quality of life was assessed by the the neck disability index, and Oswestry disability index; neck pain - on visual analog pain scale, and the range amplitude of neck movements was assessed with a goniometer.

Results. Statistically significant indicators were observed in all subject groups after rehabilitation. Pain level decreased in all groups after the study was conducted $(\mathrm{p}<0)$. Comparing the indicators between all three groups, better indicators were observed in the group of therapeutic exercises and vacuum cups whit a significant decrease in pain intensity, an increase of amplitude of neck movements and improvement in quality of life were found $(\mathrm{p}<0)$.

Conclusions. Therapeutic exercises with vacuum cups more significantly reduced pain intensity and functional disability, and more significantly increased the amplitude of active head movements compared with when other physiotherapy programs were applied.

Key words: neck pain, kinesio tape, vacuum cups, therapeutic exercises.

Gautas 2021-04-09

Priimtas 2021-05-18 